\title{
Occupational Exposure Estimate of Benzene and the Effectiveness of Control Measure in Gabon's Gasoline Storage and Distribution Facility
}

\author{
Antoine Francis Obame Nguema ${ }^{1, *}$, Akihiro Tokai ${ }^{2}$, Ibnu Susanto Joyosemito ${ }^{3}$, Naoya Kojima ${ }^{4}$ \\ ${ }^{1}$ Osaka University, Department of Engineering, Graduate School of Engineering, Division of Sustainable Energy and Environmental \\ Engineering, Environmental Management Laboratory (Tokai Laboratory). 2-1 Yamadaoka Suita City Suita, Room 502 of M 3 \\ Building, Osaka Prefecture P.o. Box: 5650871, Japan.

\begin{abstract}
${ }^{2}$ Osaka University, Department of Engineering, Graduate School of Engineering, Division of Sustainable Energy and Environmental Engineering, Area of Environmental Management 2-1 Yamadaoka Suita City Suita, M 3 Building, Osaka Prefecture P.o. Box: 5650871, Japan
\end{abstract}

${ }^{3}$ University of Bhayangkara Jakarta Raya; Faculty of Engineering, Environmental Engineering. Jl. Darmawangsa 1 No.1, Kebayoran. Baru, Jakarta 121402, Indonesia.

\begin{abstract}
${ }^{4}$ Osaka University Graduate School of Engineering Department of Environment and Energy Engineering Associate Professor of Environmental Management (Tokai Laboratory) T 565-0871 Osaka Prefecture Suita-shi Yamada Hill 2-1 M3 Building No. 510 Room, Japan

${ }^{*}$ Corresponding author's email: obame [AT] em.see.eng.osaka-u.ac.jp
\end{abstract}

\begin{abstract}
The processing of petroleum products in gasoline storage and distribution facility for loading operation, has caused the generation of vapor emissions sources. Benzene is one of those vapor emissions that workers are likely to be exposed at high exposure level during conducting out specific tasks such as loading gasoline to various petroleum storage transport modes. This results in many problems on human health such as cancer and non-cancer diseases. However, the estimate of benzene exposure to indicate the control measures has not been fully explored in previous researches. In this study, the occupational exposure estimate of benzene in Gabon's gasoline storage and distribution facility was investigated by using a quantitative and predictive exposure inhalation model; to estimate benzene concentration before and after applying control measures. The results indicate that the benzene concentrations varied between $9.46 \mathrm{mg} / \mathrm{m}^{3}$ and $187 \mathrm{mg} / \mathrm{m}^{3}$ for short term and has the value of $187 \mathrm{mg} / \mathrm{m}^{3}$ for long term. The implementation of control measures including using vapor recovery system, chemical filter mask and improving worker's behavior might contribute to significantly reduce benzene concentration to the range of $4.52-29.08 \mathrm{mg} / \mathrm{m}^{3}$ for short term and down to $4.55 \mathrm{mg} / \mathrm{m}^{3}$ for long term. This almost meets the Agency Governmental Industrial Hygienists standard, in which occupational exposure limit for short term and long term exposure is $8.1 \mathrm{mg} / \mathrm{m}^{3}$ and $3.16 \mathrm{mg} / \mathrm{m}^{3}$, respectively.
\end{abstract}

Keywords--- Benzene exposure, Task-level assessment, Control measures, Loading operations, Gasoline storage and distribution facility

\section{INTRODUCTION}

In order to convey refined petroleum products from the refinery to the end users, gasoline storage and distribution facility (GSDF) is considered as a critical step to successfully achieve this operation. GSDF is concerned with the handling for storage and transfer of refined petroleum products in loading locations via pipelines to different petroleum storage transport mode (barge tanks, truck tank) [1,2,]. GSDF is as the same time a useful tool for a nation's economic growth and health issue to its working population; through economic gain from loading operations activities and health damage such as cancer risk from workers' exposure to petroleum products respectively. Loading operation is the process of transferring petroleum refined products from storage tank to operating tank [2]. It is also the transfer of petroleum refined products from storage tank to various petroleum storage transport mode such as; barge tank; truck tank, through pipelines, hoses, flexible joint arms [1]. Loading operation is the main activity in petroleum storage and distribution facility and required well trained working force and functional equipment to be run properly [2]. These requirements act as a guarantee for a safe working environment freed from any economic loss and occupational injure. However, during loading operations and storage of petroleum refined products, such as gasoline, benzene vapors escape into the atmosphere [3]. Air toxics are 
released from the petroleum storage and distribution facility during gasoline loading tank truck; storage tank; barge tank and from the vapor leaks at loading pumps, valves and other equipment in the facility $[2,4]$.

Benzene is one of the volatile components of petroleum products, like gasoline and is an established carcinogenic chemical for human health by the International Agency of Research on Cancer [5]. Short term high exposures to benzene on human can give rise to various adverse effects such as headaches, dizziness, inability to concentrate, impaired short term memory and tremors [6,7] and is considered as acute exposure effects. While long term human exposure can give rise to more complex health effects including haematotoxicity, genetoxicity, immunological and reproductive effects as well as various cancers [8] and is considered as chronic exposure effects. In general, acute exposure effects are considered to be reversible, while chronic exposure effects are probably irreversible [9]. Gabon is a third-world oil exporting country since 1960. Specific hazardous working environments in the oil sector called "classified petroleum facilities" with environmental and occupational regulations have been set-up since 2005 [10]. These regulations allow the evaluation of hazardous chemical in "classified petroleum facilities" [11]. Gabon's regulations related to chemical inhalation exposure from GSDFs do not meet the current international standards. Additionally, monitoring data for previous assessment are unavailable. Because it is frequently not feasible to measure the exposure of all workers due to limited resources. The lack of using a model that estimate exposure and systematically evaluate the control measures in previous studies for Gabon's GSDFs, makes it challenging to provide an accurate risk assessment of inhalation exposure to hazardous substances. Therefore, in this study, a modeling estimation is recommended. To overcome monitoring challenges and compensate the lack of measured data. The Risk Assessment Regulation (1488/94) allows the use of modeling techniques for the estimation of exposure [12]. Loading operations are characterized by various subtasks which produce vapor emissions [13] and which need to be estimated in other to know the level of exposure concentration workers are exposed to. Modeling techniques help to estimate chemicals emissions from these subtasks. To the task-level assessment of benzene exposure [14], some predictive exposures models were built, such as European Centre For Ecotoxicology and Toxicology Of Chemicals - Targeted Risk Assessment (ECETOC-TRA) Model, is effective on dermal exposure and chemical properties assessment [15]; the Estimation and Assessment of Substance Exposure (EASE) Model has few features as predictive exposure model [16]; and the Control of Substances Hazardous to Health (COSHH) Essential is a generic exposure predictive model [17]; all have been proposed to assess benzene exposure in GSDF. However, these predictive exposures models provide an estimation of exposures concentrations less accurate regardless of GSDF. Further, without ensuring a safe level of workplace [18], therefore, maintaining a potential high risk on exposure in loading operations. These exposures predictive models are limited to conduct a task process assessment and a systematic control measures assessment effectively for benzene exposure during loading operation in GSDF. Despite this concern, few detailed researches have been conducted on occupational benzene exposure with a systematic reduction strategy in GSDFs. In order to provide a more accurate estimate exposure concentration with the view of procuring safe working environment. Thus, this study aims to estimate benzene exposures concentrations at the task-levels and evaluate the effectiveness of appropriates control measures to reduce exposure concentrations to the occupational exposure limit (OEL) for loading operations in Gabon's GSDFs. Fig. 1 shows the overall research framework.

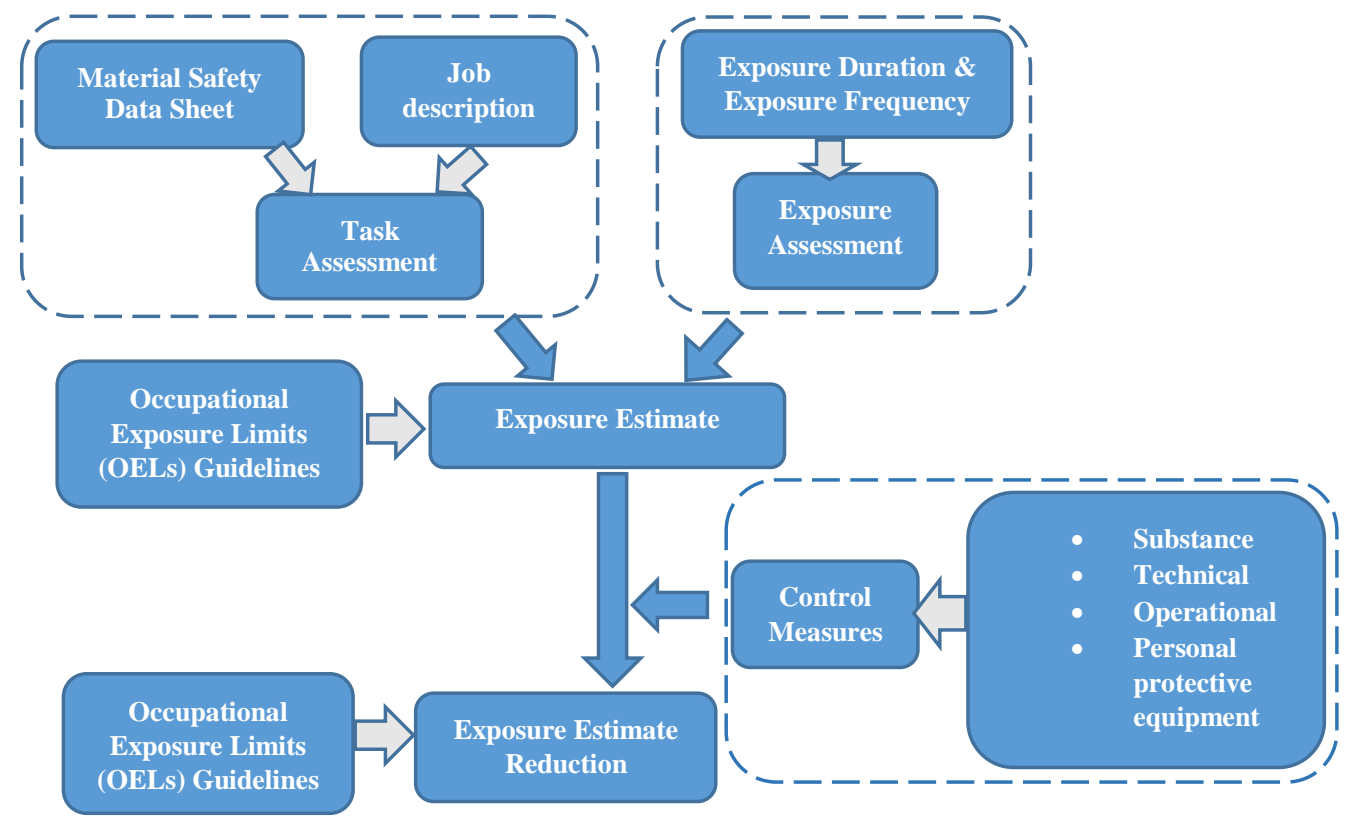

put at each step of the framework

. at needed at each step of the framework

Figure 1. Research framework 


\section{MATERIALS AND METHODS}

In section 2.1., benzene international regulations and; the standards for OEL as well as the standard for risk reduction measure in handling gasoline are explained. Section 2.2. briefly explains the typical situation of the Gabon's GSDF. Section 2.3. presents the estimation method based on task exposure assessment. Finally, section 2.4., assesses control measures and estimates the reduction of exposure concentrations. This method enables the estimation of benzene exposure concentration at the tasks level and lower the exposure level to the OEL.

\subsection{International regulations and standards for benzene $O E L$}

In the petroleum industry, GSDFs are known to result as the highest occupational exposures to chemical [19]. The introduction of various strategies to provide workers a safe working place has been evolving for over six decades. Several specific control measures in general from industrialized countries, those specifics to GSDF have been suggested. The implementation of Stage I vapor recovery (the equipment used to capture and recover emissions from loading operations in GSDF) [20] has become a requirement to adhere to stringent limits on emissions in several countries; under the National Emission Standards for Hazardous Air Pollutant (NESHAP) regulations [21]. Edokpolo [7] showed that the vapor recovery system led to significant great reduction in benzene exposure levels in petroleum distribution facilities [21].

Table 1. Gasoline regulations in petroleum storage and distribution facility

\begin{tabular}{|c|c|c|c|}
\hline Tasks & $\begin{array}{l}\text { Regulations titles \& } \\
\text { scopes }\end{array}$ & Explanations & References \\
\hline $\begin{array}{l}\text { Loading } \\
\text { truck } \\
\text { tank }\end{array}$ & $\begin{array}{l}\text { Loading operation of } \\
\text { gasoline from a loading } \\
\text { rack to the truck tank } \\
\text { must comply with the } \\
\text { New Source } \\
\text { Performance Standards } \\
\text { codified at the } 40 \text { Code } \\
\text { of Federal Regulations } \\
\text { (C.F.R.) }\end{array}$ & $\begin{array}{l}\text { This regulation contributes to } \\
\text { lowering VOC emissions during the } \\
\text { truck tank loading operation. The } \\
\text { loading racks must be equipped } \\
\text { with a vapor collection system } \\
\text { designed to collect the total organic } \\
\text { compound (TOC). Loading rack } \\
\text { equipped with a vapor collection } \\
\text { system must not exceed emission of } \\
35 \mathrm{mg} \text { of TOC per liter of gasoline } \\
\text { loaded (mg TOC/L gasoline), or } \\
\text { 80mg TOC/L gasoline loaded. } \\
\text { Gasoline must only be loaded into a } \\
\text { vapor-tight gasoline truck tank. }\end{array}$ & $\begin{array}{l}40 \text { C.F.R. Part 60, Subpart XX - } \\
\text { Standards of Performance for Bulk } \\
\text { Gasoline Terminals. Standard of } \\
\text { Performance Standards New Stationary } \\
\text { Sources, 2013: } \S 60.500-60.506 \\
\text { Standard of Performance Standards New } \\
\text { Stationary Sources, 2013: } \S \text { 60.500- } \\
60.502 \text { (a) Standard of Performance } \\
\text { Standards New Stationary Sources, } \\
\text { 2013: } \S 60.500-60.502(b)(c) \\
\text { Standard of Performance Standards New } \\
\text { Stationary Sources, 2013: } \S \S 60.500- \\
60.502(e)\end{array}$ \\
\hline $\begin{array}{l}\text { Loading } \\
\text { storage } \\
\text { Tanker }\end{array}$ & $\begin{array}{l}\text { Loading tanker } \\
\text { operation must comply } \\
\text { with the emission limits } \\
\text { and management } \\
\text { practices set forth at the } \\
40 \text { C.F.R., Part 63, } \\
\text { Subpart R }\end{array}$ & $\begin{array}{l}\text { Leakages equipment within the } \\
\text { GDSF, must control VOC } \\
\text { emissions from large storage tanks } \\
\text { (i.e. those at or above } 20,000 \\
\text { gallons' capacity) by installing } \\
\text { either specified floating roofs and } \\
\text { seals or at closed vent system and } \\
\text { control device to reduce emissions } \\
\text { by } 95 \% \text {. }\end{array}$ & $\begin{array}{l}40 \text { C.F.R., Part 63, Subpart R. NESHAP } \\
\text { for Hazardous Air Pollutants for Source } \\
\text { Categories, 2013: } \$ 63.422 \text { (b) } \\
\text { 40 C.F.R., Part 63, Subpart R. NESHAP } \\
\text { for Source Categories, 2013: } \$ 63.423 \text { (b) } \\
\text { Transportation of Hazardous Liquids by } \\
\text { pipeline, 2013: } \S \S 195.100-195.134 \text {; } \\
\text { 195.402-195.403; 195.48-195.64 } \\
\text { NESHAP. Ill. Administration. Code, Tit. } \\
\text { 35, } \S 215.583,218.583,219.583 \text { and } \\
\text { Michigan. Administration. Code, } \\
\text { r.336.1606-336.1703 }\end{array}$ \\
\hline $\begin{array}{l}\text { Loading } \\
\text { barge }\end{array}$ & 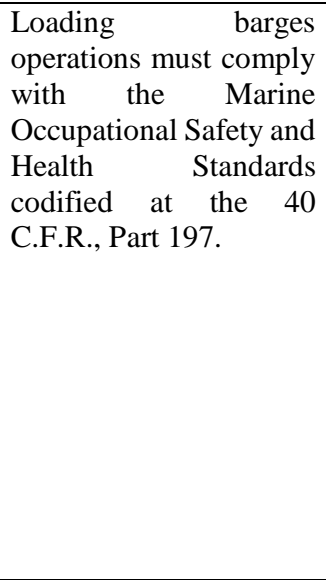 & $\begin{array}{l}\text { The observation of the permissible } \\
\text { exposure limits (PELs) for benzene } \\
\text { and wearing respirators and } \\
\text { personal protective equipment in } \\
\text { areas where airborne benzene } \\
\text { concentration can be expected to } \\
\text { exceed the PELs must be complied. } \\
\text { Additionally, workers should be } \\
\text { informed about benzene hazards, } \\
\text { including the Material Safety Data } \\
\text { Sheet (MSDS) and trained } \\
\text { regarding benzene risk and } \\
\text { protective measures. Workers must } \\
\text { be removed from areas where the } \\
\text { airborne concentration may exceed } \\
5 \text { ppm. }\end{array}$ & $\begin{array}{l}\text { 40 C.F.R., Part 197. General Provisions: } \\
\text { Marine Occupational Safety and Health } \\
\text { Standards, 2013: } \S 197.515,197.520 \text { and } \\
197.535 \\
\text { 40 C.F.R., Part 197. General Provisions: } \\
\text { Marine Occupational Safety and Health } \\
\text { Standards, 2013: } 197.565 \text {. } \\
\text { 40 C.F.R., Part 197. Subpart C. General } \\
\text { Provisions: Marine Occupational Safety } \\
\text { and Health Standards, 2013: } § 197.560 \text {. }\end{array}$ \\
\hline
\end{tabular}


Furthermore, Swick et al. [22] have inventoried the latest regulations related to the handling of hazardous substances in the workplace, especially for gasoline product, which contains benzene as substance. A summary of these regulations is shown in Table 1. According to the 1994 European Commission Directive 63/94/EC, storage installations as well as loading and unloading equipment must be designed and operated in accordance with the technical provisions to reduce emissions of volatile organic compound [3]. Benzene is known to adversely affect human health and therefore, regulations have been promulgated to reduce the amount of benzene to which workers and general public are exposed to [21]. Regulatory OELs, based on toxicology data, are set and enforced by government agencies to protect workers' health in the workplace [23]. However, the level of regulations standards for benzene exposure in GSDF can differ from one facility to another; and from one country's legislation to another. These are guided by specifications of benzene on the petroleum product, engineering controls via good industry working practices existing in a country's legislation, or by the company's safety and health guidelines [22]. For the Gabon's GSDF, the Gabonese Hydrocarbon Code, Law No 011/2014 remains unsatisfactory regulations for gasoline storage and distribution industry in comparison to the current international standards. The adoption and the implementation of more mature regulations from international standards by Gabon's GSDF, for its loading operations in reference to the Table 1 would determine the level of exposure to benzene in the facility. Table 2 presents the current OELs of benzene from various regulatory bodies [7]. These regulations are used worldwide and are based on epidemiological studies. The current guidelines to assess exposure concentration levels of benzene in occupational settings have also been presented.

Table 2. Occupational exposure limits of benzene

\begin{tabular}{|c|c|c|}
\hline Regulatory body & Description & Benzene $\left(\mathrm{mg} / \mathrm{m}^{3}\right)$ \\
\hline \multicolumn{3}{|c|}{ Occupational Exposure Limits (OEL) } \\
\hline \multirow{2}{*}{$\begin{array}{lr}\text { American } & \text { Conference } \\
\text { of } \quad \text { Governmental } \\
\text { Industrial } & \text { Hygienists } \\
\text { (ACGIH), USA }\end{array}$} & Threshold Limit Values (TLV/8hour) & 1.6 \\
\hline & $\begin{array}{lccc}\text { Short } & \text { Term } & \text { Exposure } & \text { Limit } \\
(\text { STEL/15mn) } & & \end{array}$ & 8.1 \\
\hline \multirow{2}{*}{$\begin{array}{l}\text { Occupational Safety and } \\
\text { Health Administration } \\
\text { (OSHA), USA }\end{array}$} & Permissible Exposure Limit (PEL/8hour) & 3.25 \\
\hline & $\begin{array}{lccc}\begin{array}{l}\text { Short } \\
(\text { STEL/15mn) }\end{array} & \text { Exposure } & \text { Limit } \\
\end{array}$ & 16.25 \\
\hline \multirow{2}{*}{$\begin{array}{l}\text { National Institute for } \\
\text { Occupational Safety and } \\
\text { Health (NIOSH), USA }\end{array}$} & $\begin{array}{l}\text { Recommended } \\
\text { (REL/8hour) }\end{array}$ & 0.325 \\
\hline & $\begin{array}{l}\text { Short Term } \\
\text { (STEL/15mn) }\end{array}$ & 3.25 \\
\hline
\end{tabular}

\subsection{Gabon's GSDTF}

Several studies, such as those by Irving et al., [32] (422.5 mg/m $\left.\mathrm{m}^{3}\right)$ Saarinen., $\left(6.1 \mathrm{mg} / \mathrm{m}^{3}\right)$, and Thomas J. Smith et al., [37] $\left(1625 \mathrm{mg} / \mathrm{m}^{3}\right)$ have reported short-term exposure at high concentration during loading operations in GSDFs without vapor recovery system. The Gabon's GSDF is located in the Maritime-Ogooue Province in western side of Gabon. An average of more than 765492 tonnes of refined petroleum products are handled every year [24]. The facility has a pipeline system network connected to the only refinery for receiving petroleum products into storage tanks. The facility possesses a loading rack area for truck tank loading operations and a pumping station for barge loading operations. All the operations are done manually. Additionally, the facility does not have a vapor recovery system for its loading operations as required from the current regulation. Therefore, the gasoline vapor escapes into the atmosphere during storage and loading operations [22]. The main activity at Gabon's GSDF is the loading operation. Loading operation is the transfer of petroleum product from the refinery to the storage tank, the storage tank to the truck tank, or barge tank through pipeline and flexibly jointed loading arms $[1,2]$. Loading operation is also, a process of combining separated subtasks with the view of transferring refined petroleum products from one storage mode to another. These subtasks operations indicate usually higher benzene exposure concentration for short term exposure and low exposure concentration for the full shift ( 8 hours - TWA) for the two OELs. In general, short term exposure task during loading operations involve highly variable exposure exceeding the OEL [25]. Thus, this leads to a necessity to perform task-level assessment in GSDF.

\subsection{Task-level assessment method}

Three operations were selected at the Gabon's GSDF, “tank truck loading operation"; “'storage tank loading operation", and "barge loading operation". These loading operations are at different locations and task are performed through different equipment in the facility such as; loading truck tank from flexible arms; loading storage tank from the pipeline, and loading barge from hoses. Subsequently, the job description of each operation was analyzed in details in order to identify the subtasks where workers are directly exposed to benzene exposure. The analysis resulted in the identification of the sources 
of vapor emission; worker's breathing zone and actions during loading operations that exposed the workers to benzene inhalation. The Figure 2. shows the exposure process by which workers are potentially exposed to chemical substance during a task. Data on the duration and frequency of each exposures situations were also collected from sample survey of regular loading operation in GSDF. These parameters were used to estimate the benzene concentration in the various loading locations. The Table 3. summarize the parameters used to estimate the benzene concentration. Long term exposure subtask (LTES), were defined as those with an exposure duration time > 30 minutes and short exposure subtasks (STES), as those with an exposure duration time $<30$ minutes. The Material Safety Data Sheet (MSDS) for gasoline from SHELL Company was used. The gasoline MSDS was obtained through an internet search engine such as Google. Information concerning health and safety, such as "risk-phrases" and "health-statement" were retrieved from this MSDS. This information enabled to identify the severity level of benzene hazardous to human health. The "health - statement" was ranked into hazard classes according to the severity towards human health. According to this MSDS, the gasoline product was composed of 13 components. The component referred into this study is benzene. These information lead to the estimation of the benzene intrinsic emission, the first element in the exposure process as shown in the figure 2.

Table 3. Benzene exposure parameters

\begin{tabular}{|c|c|c|c|}
\hline Operations & Tasks & Time (minutes) & Frequency \\
\hline \multirow{4}{*}{$\begin{array}{l}\text { Truck tank } \\
\text { Loading }\end{array}$} & $\begin{array}{l}\text { checking the } \\
\text { manholes (STET) }\end{array}$ & 3 & 4-5 day a week \\
\hline & $\begin{array}{l}\text { loading truck tank } \\
\text { (STET) }\end{array}$ & 25 & 4-5 day a week \\
\hline & $\begin{array}{l}\text { cleaning spillage } \\
\text { and leaks (STET) }\end{array}$ & 10 & 4-5 day a week \\
\hline & $\begin{array}{l}\text { taking the product } \\
\text { sample (STET) }\end{array}$ & 2 & 4-5 day a week \\
\hline \multirow{3}{*}{$\begin{array}{l}\text { Storage tank } \\
\text { Loading }\end{array}$} & $\begin{array}{ll}\text { tanker } & \text { gauging } \\
\text { (STET) } & \end{array}$ & 3 & 4-5 day a week \\
\hline & $\begin{array}{l}\text { loading storage tank } \\
\text { (LTET) }\end{array}$ & 360 & 4-5 day a week \\
\hline & $\begin{array}{l}\text { taking the product } \\
\text { sample (STET) }\end{array}$ & 2 & 4-5 day a week \\
\hline \multirow{3}{*}{$\begin{array}{l}\text { Barge } \\
\text { Loading }\end{array}$} & $\begin{array}{l}\text { opening valve } \\
\text { system (STET) }\end{array}$ & 3 & 2-3 day a week \\
\hline & $\begin{array}{l}\text { Loading and pump } \\
\text { monitoring (LTET) }\end{array}$ & 360 & 2-3 day a week \\
\hline & $\begin{array}{l}\text { taking the product } \\
\text { sample (STET) }\end{array}$ & 2 & 2-3 day a week \\
\hline
\end{tabular}

In order to estimate exposures at the task process level, scores were assigned at each task process steps. These scores of various values were attributed regardless of the chemical dispersion process according to Cherrie et al. [26]. The logarithmic scale is based on 'source-receptor' approach, of the conceptual model for inhalation exposure assessment [27]. From the emission source of the contaminants to the worker, through the exposure patterns, several modifying factors were identified. The conceptual model in inhalation exposure assessment is built from nine (9) mutually independent principal modifying factors [31]. These modifying factors describe the components and the transport mechanism of exposure process at high level and an approach for exposure quantification $[29,30]$. The main source of emission being the loading operations, the figures 3, 4, 5 below describe the specific sources locations as well as the corresponding tasks. Fig. 3 shows the truck tank loading operation and describes the task and localizes the source of vapor benzene emission. Fig. 4 shows the storage tank loading operation and describes the task and the source of vapor benzene emission area. Finally, Fig. 5 indicates the barge loading operation and describes the task and identifies the source of vapor benzene emission location. 
Table 4. Logarithm scale for category scores of dispersion exposure

\begin{tabular}{|l|l|}
\hline None & 0 \\
\hline Very low & 0.03 \\
\hline lower & 0.1 \\
\hline Low & 0.3 \\
\hline Medium & 1 \\
\hline High & 3 \\
\hline Very high & 10 \\
\hline
\end{tabular}

The exposure predictive model used in this study has been validated from various studies such as those by Koppisch et al., [27], and Landberg et al., [28]. In order to estimate the benzene exposure concentration level at the Gabon's GSDF, the facility was divided into three main compartments with regards to breathing zones, i.e: We have "near-field exposure", "far-field exposure", and "background exposure". A source of emission that is relatively far from a worker has a lower influence on the worker than a source very close to the worker. Several equations, in total 9 were applied to quantify the benzene concentration at different levels of exposure during the tasks, are mentioned below. These equations follow the work of Tielemens, [31] and express the development of a quantitative algorithm for exposure predictive model $[29,30]$. The equation for intrinsic emission of benzene, was applied to determine the concentration level of benzene within the product (gasoline). Before, any modifying factors can either increase or decrease the concentration level. The equation on intrinsic emission is described below as: The intrinsic emission of benzene equation:

$E b=P b / 30000 P a \times f b(1)$

Eb : intrinsic emission of benzene $\left(\mathrm{mg} / \mathrm{m}^{3}\right) \mathrm{Pb}$ : vapor pressure of pure benzene substance $(\mathrm{kPa}) \mathrm{fb}$ : the fraction of benzene component in gasoline 30, $000 \mathrm{~Pa}$ : substances with a vapor pressure equal or superior to 30, $000 \mathrm{~Pa}$ which fully evaporated in a very short time and will practically only be available as vapor.

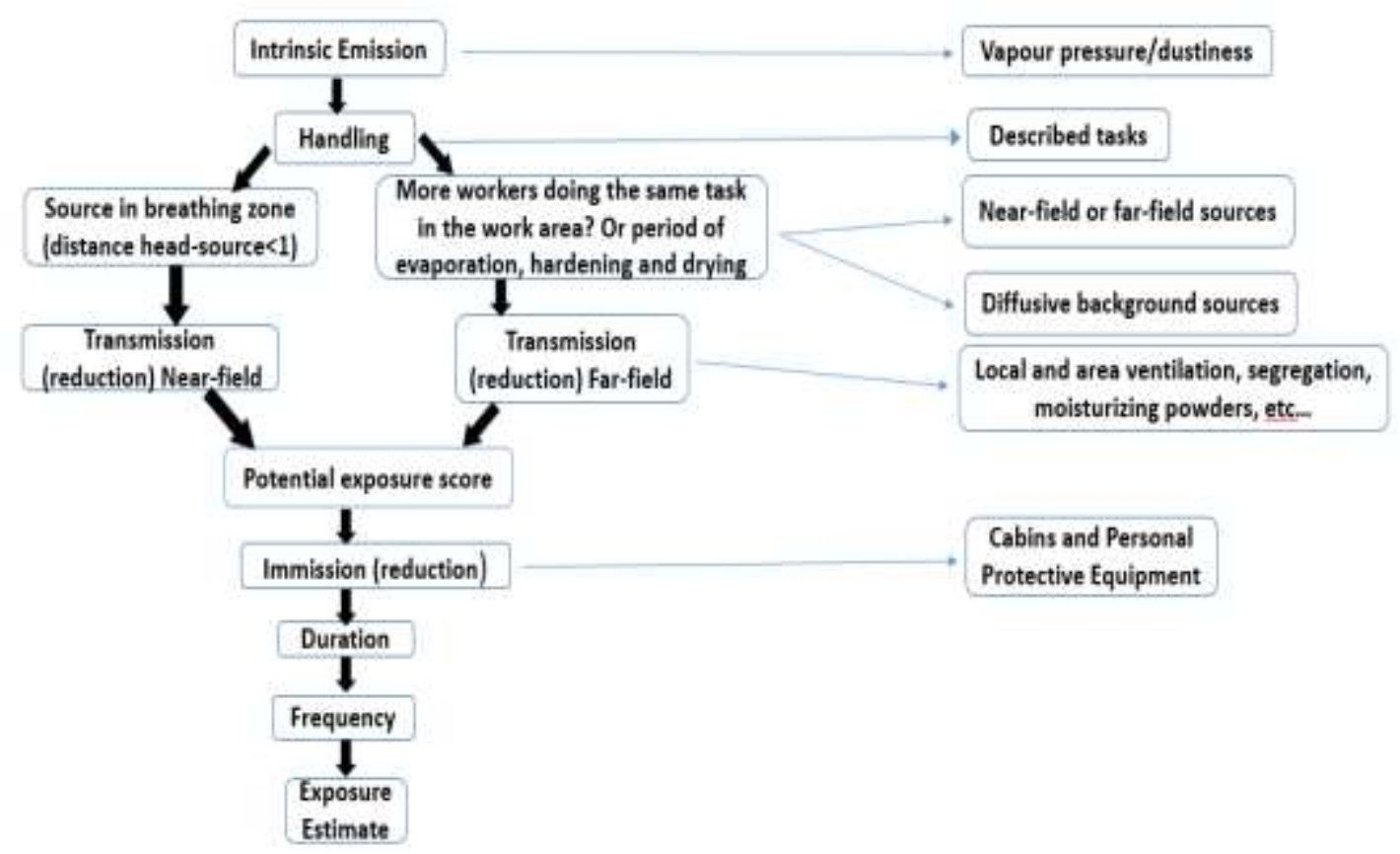

Figure 2. Exposure process

The "near-field exposure" was considered as exposure concentration level taking at the source located within one (1) meter of the head of the worker (Hanna et al., 2017). That is, within a one meter of the area where task is being performed.

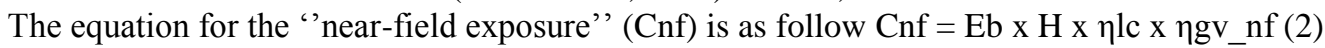


The far-field exposure (Cff) was considered as the exposure concentration level taking within one to four meter of the source of emission within the breathing zone. That is, one (1) to four (4) meter away far from where the task is performed. The equation for the far-field exposure is as follows:

$$
\mathrm{Cff}=\mathrm{Eb} \times \mathrm{H} \times \eta \mathrm{lc} \times \operatorname{\eta gv}_{-} \mathrm{ff}(3)
$$

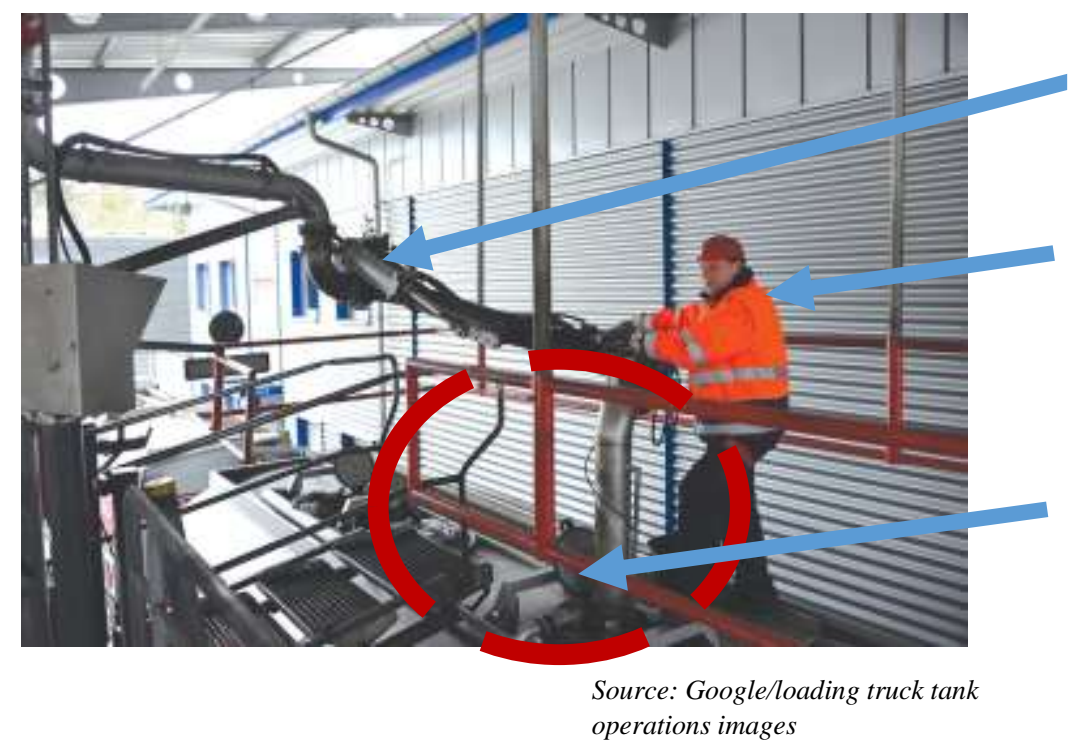

Loading arm

Worker

Source of

emission

Figure 3. Truck tank loading operation

The background exposure (Cds) was considered as the exposure concentration level taking beyond the four (4) meter of the emission source and was described as when there is no loading operation taking place in the facility. The equation for the background exposure is as follows:

$\mathrm{Cds}=\mathrm{Eb} \times \mathrm{a}(4)$

The daily concentration $(D c)$ is the average exposure concentration for the traditional 8 hour working time for loading operations tasks. The equation for of the daily concentration is as follows:

$$
D c=C f f x \operatorname{Cnf} x \text { fh } x \text { th }(8 h)(5)
$$

The long-term exposure concentration (Ltec) is the exposure concentration of tasks above 30 min. The equation of the long- term exposure concentration is as follows:

$$
\text { Ltec }=\text { Cff } x \text { Cnf } x \text { th }(<30 m n)(6)
$$

The short -term exposure concentration (Stec) is the exposure concentration of tasks less than inferior to 30 min. The equation of the short -term concentration is as follows:

$$
\text { Stec }=\text { Cff } x \text { Cnf } x \text { th }(>30 m n)(7)
$$

Eb: the intrinsic emission of benzene $\left(\mathrm{mg} / \mathrm{m}^{3}\right) \mathrm{H}$ : handling (or task); (dimensionless) $\eta$ lc: local control measures of the existing reduction transmission; (dimensionless) $\eta g v$ : Natural ventilation of the existing reduction transmission; (dimensionless) th: handling time; minutes (min) fh: frequency of handling; length of exposed time * time in minutes $\left(N^{*}\right.$ min) Cds: background exposure; $\left(\mathrm{mg} / \mathrm{m}^{3}\right)$ Dc: daily concentration task; $\left(\mathrm{mg} / \mathrm{m}^{3}\right)$ Ltec: long- term exposure concentration; $\left(\mathrm{mg} / \mathrm{m}^{3}\right)$ Stec: short -term exposure concentration; $\left(\mathrm{mg} / \mathrm{m}^{3}\right)$ Cnf: near-field exposure concentration task $\left(\mathrm{mg} / \mathrm{m}^{3}\right)$ Cff: far-field concentration task $\left(\mathrm{mg} / \mathrm{m}^{3}\right)$ 


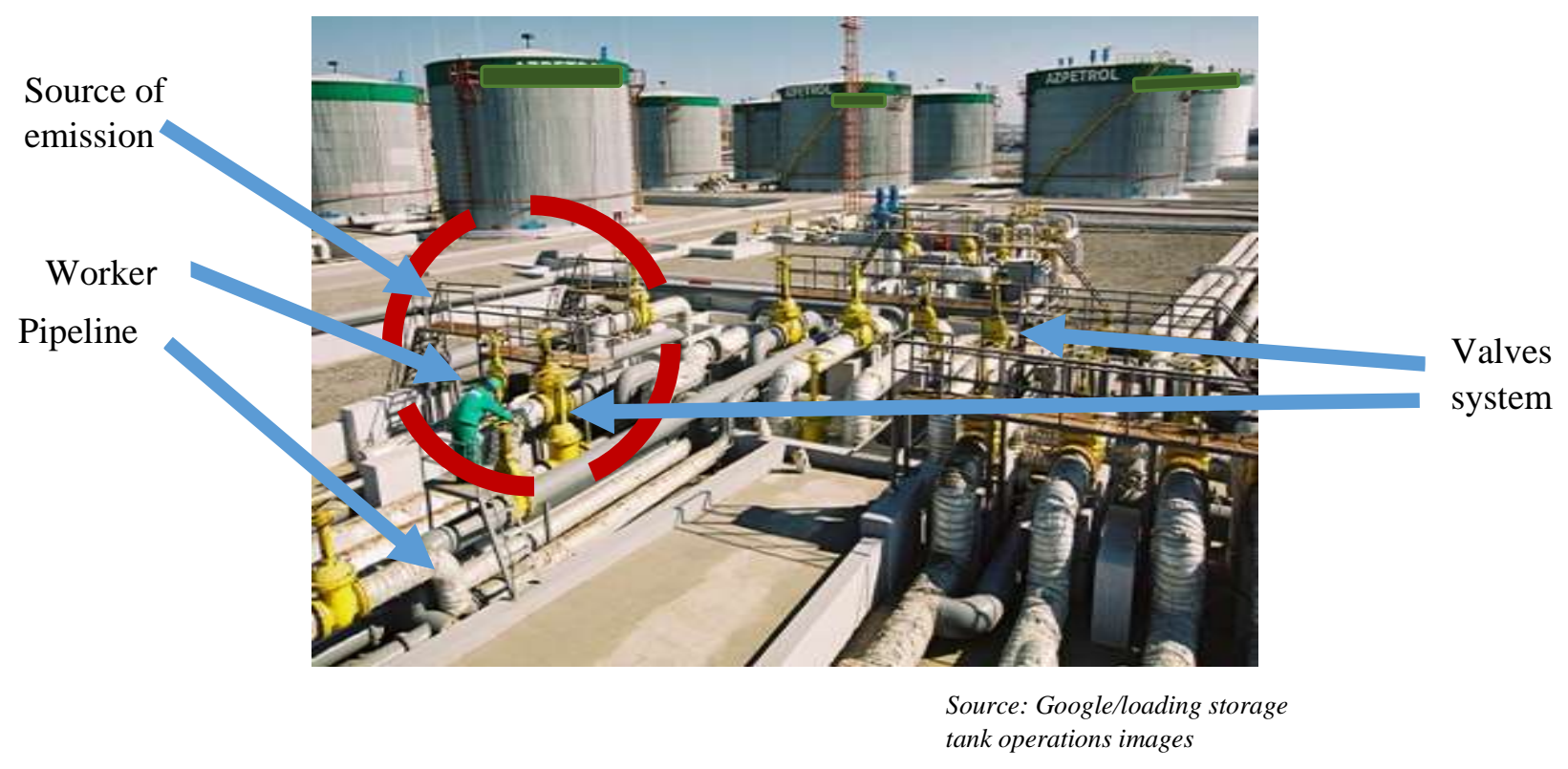

Figure 4. loading storage tank operation

From the above equations, the concentrations for STES and LTES during loading operations were performed and known. This leads after, to the reduction of the exceeded concentration levels to the OELs.

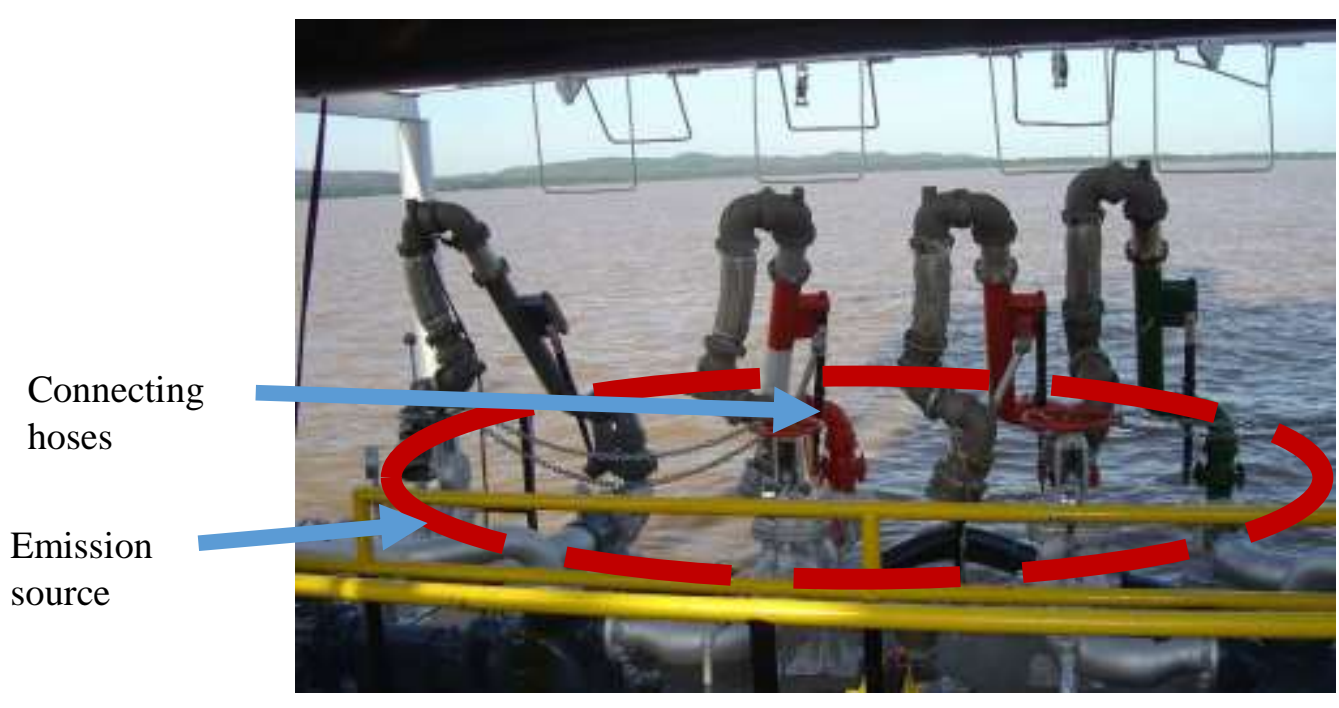

Figure 5. loading barge operation

Source: Google/loading barge operations images

\subsection{Control measures assessment}

The reduction strategy for benzene was addressed at four levels. The measures that impact "near-field" level; the measures affecting the "far-field" level; the measures impacting the "background" level, and the measures influencing the "adaptation of worker situation", These measures are based on the hierarchical so-called "S.T.O.P.-principal" (substitution measures, technical measures, operation measures, personal protection equipment). Each of these control measures represent a group of various control measures assigned to reduce exposure concentration in their particular 
dimension level. Thus, we have "chemical filter mask" control measure for the " personal protection equipment" control measure group or the "vapor recovery system"' control measure as part of the "technical" control measures group. For every single subtask, relevant control measures were applied at each level from one step to the other. The relevant controls measure of the "substitution measures" group were applied before moving to next group, i.e., "technical measures" to reach the OELs [31]. To lower the concentrations of benzene to OELs during loading operations, the following reduction equations were used.

Concentration reduction near-field:

Cr.nf $=$ Cnf $x$ iimm (8)

Concentration reduction far-field:

$C r . f f=C f f x \operatorname{\eta imm}(9)$

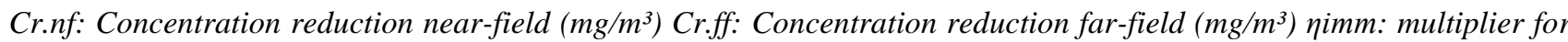
the reduction of exposure due to control measures at work.

\section{RESULTS \& DISCUSSION}

The results presented here are based on a case study, investigating the estimation of benzene exposure concentration for STES and LTES during loading operations at the Gabon's GSDF. In total, from the three loading operations in this facility (loading truck tank operation, loading barge operation, and loading storage tank operation), ten exposures subtasks were assessed. Among all the exposures subtasks, we have eight STES concentrations and two LTES concentrations.

\subsection{Benzene exposures concentrations during loading operations}

\subsubsection{Loading truck tank operation}

The loading truck tank operation presented four (4) subtasks situations, where the workers were considerably exposed to benzene. The benzene concentration of these subtasks varied from $9.86 \mathrm{mg} / \mathrm{m}^{3}$ to $187 \mathrm{mg} / \mathrm{m}^{3}$. The benzene concentration exceeded the $8.1 \mathrm{mg} / \mathrm{m}^{3}$ Occupational Exposure Limits-Short Term Exposure Limit (OELs-STEL) of the American Conference of Governmental Industrial Hygienists (ACGIH), regulatory value for the 15 min STES. Equations (5), (7) were used in all the subtasks for "daily concentration" and "task benzene concentration" respectively during "truck tank loading operation". A difference between the short- term concentrations and daily concentration of the subtasks was noticed. Another contrast was observed between the short- terms concentrations, where, as shown in Fig.6, the subtasks "checking the manholes" and; "loading truck tank" has significantly higher concentrations than the subtasks "cleaning spillage and leaks", and; "taking the product sample". From these concentration variations, it can be inferred that, the nature of the subtask being performed is the primary determinant of the overall benzene exposure [14]. The Figure 6. presents the difference in benzene exposure concentrations for different subtasks and their daily concentrations during the "'loading truck tank operation'. This high difference implies the relevance of conducting more task exposure assessments compared to daily concentrations as recommended by Verma [20].

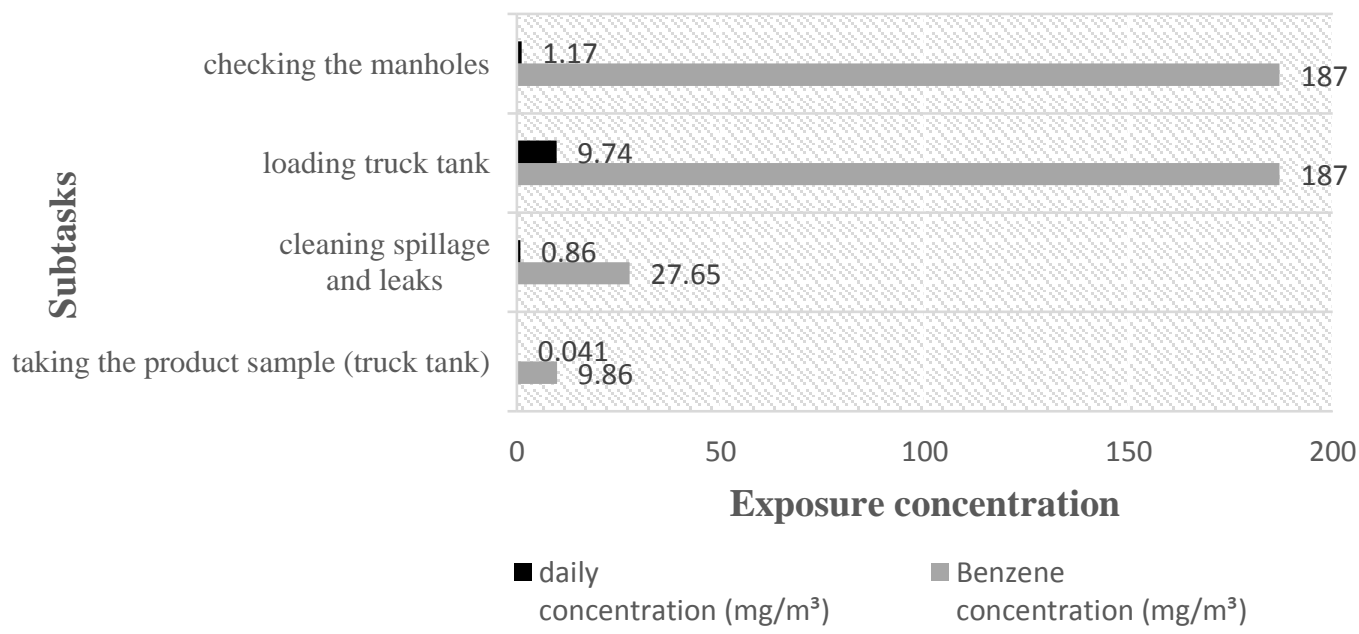

Figure 6. Benzene exposure concentrations for 'loading truck tank operation'. 


\subsubsection{Loading storage tank operation:}

In this study, the estimation of exposure concentrations on benzene for the "loading storage tank operation" were investigated for each of the subtasks. In calculating the "benzene concentration" of the subtasks: "loading storage tank"; "tank gauging", and "taking product sample"; the equation (6) was used for the first subtask and equation (7) for the other two subtasks respectively. In order to calculate the "daily concentration" of benzene exposure for all the subtasks of loading storage tank operation, we used the equation (5). All the subtasks, exceeded the $8.1 \mathrm{mg} / \mathrm{m}^{3}$ OELs-STEL from the ACGIH-TLV. The "benzene concentration" from the "tank gauging"' subtask $\left(187 \mathrm{mg} / \mathrm{m}^{3}\right)$ and the "'loading storage tank" task $\left(187 \mathrm{mg} / \mathrm{m}^{3}\right)$ indicated high level of exposure concentration compared to the "taking product sample" subtask $\left(9.45 \mathrm{mg} / \mathrm{m}^{3}\right)$. Thus, revealing that high concentrations are experienced during loading operations in a facility without a vapor recovery system [3; 32]. The "daily concentrations" of LTES $\left(140 \mathrm{mg} / \mathrm{m}^{3}\right)$ were significant compared to the STES $\left(0.74 \mathrm{mg} / \mathrm{m}^{3} ; 1.95 \mathrm{mg} / \mathrm{m}^{3}\right)$ concentrations. Only the "daily concentration"' of the LTES $\left(140 \mathrm{mg} / \mathrm{m}^{3}\right)$ was above of the TVL-TWA $\left(3.18 \mathrm{mg} / \mathrm{m}^{3}\right)$. This shows that, time is the determinant of "daily concentration" exposure for this subtask. Figure 7. highlights the difference of benzene concentration between each of the subtasks for "daily concentration", and "task benzene concentration" during "loading storage tank operation". This difference in benzene concentrations implies that subtasks exposure assessment are more relevant and give an insight than the daily concentrations for "loading storage operation',

\subsubsection{Loading barge operation:}

The "loading barge operation" indicates high exposures concentrations of benzene for all the subtasks with regards to the $8.1 \mathrm{mg} / \mathrm{m}^{3}$ OEL of STEL-TLV from the ACGIH. The equation (5) was used to calculate the "daily concentration", for all the subtasks. In order to calculate the "benzene concentration", equation (6) was used for the subtask: "loading and pump monitoring", and equation (7) was used for the subtasks: "opening a valve system" and "taking product sample". As shown in the Fig.8, the benzene concentrations for the subtasks " opening valve system", "loading and the pump monitoring', and 'taking product sample', were $187 \mathrm{mg} / \mathrm{m}^{3} ; 187 \mathrm{mg} / \mathrm{m}^{3}$, and $9.46 \mathrm{mg} / \mathrm{m}^{3}$, respectively. The exposure concentration of the STES “opening valve system" and the LTES "loading and the pump monitoring" were significant. This implies that, high exposure concentrations of benzene during loading barge are driven primarily by a few specific tasks (Robinson et al., 2005). According to Kawai et al. (Kawai et al., 1990), jobs involving benzene during loading operations of barges were often associated with higher exposure (Walker et al., 2014). The "daily concentration", of the tasks "'opening valve system", and "taking product sample", were within the $3.18 \mathrm{mg} / \mathrm{m}^{3}$ OELs of the TVL-TWA from ACGIH. However, the LTES for "loading and the pump monitoring" significantly exceeded the "daily concentration"' exposure $\left(140 \mathrm{mg} / \mathrm{m}^{3}\right)$. Fig. 8 presents the estimation value of "benzene concentrations" and the "daily concentrations" for all subtasks during the "loading barge operation". The difference in benzene exposure concentrations indicates that the exposure concentration level of the task being performed is highly influenced by the specificity of the task in the gasoline storage and distribution industry.

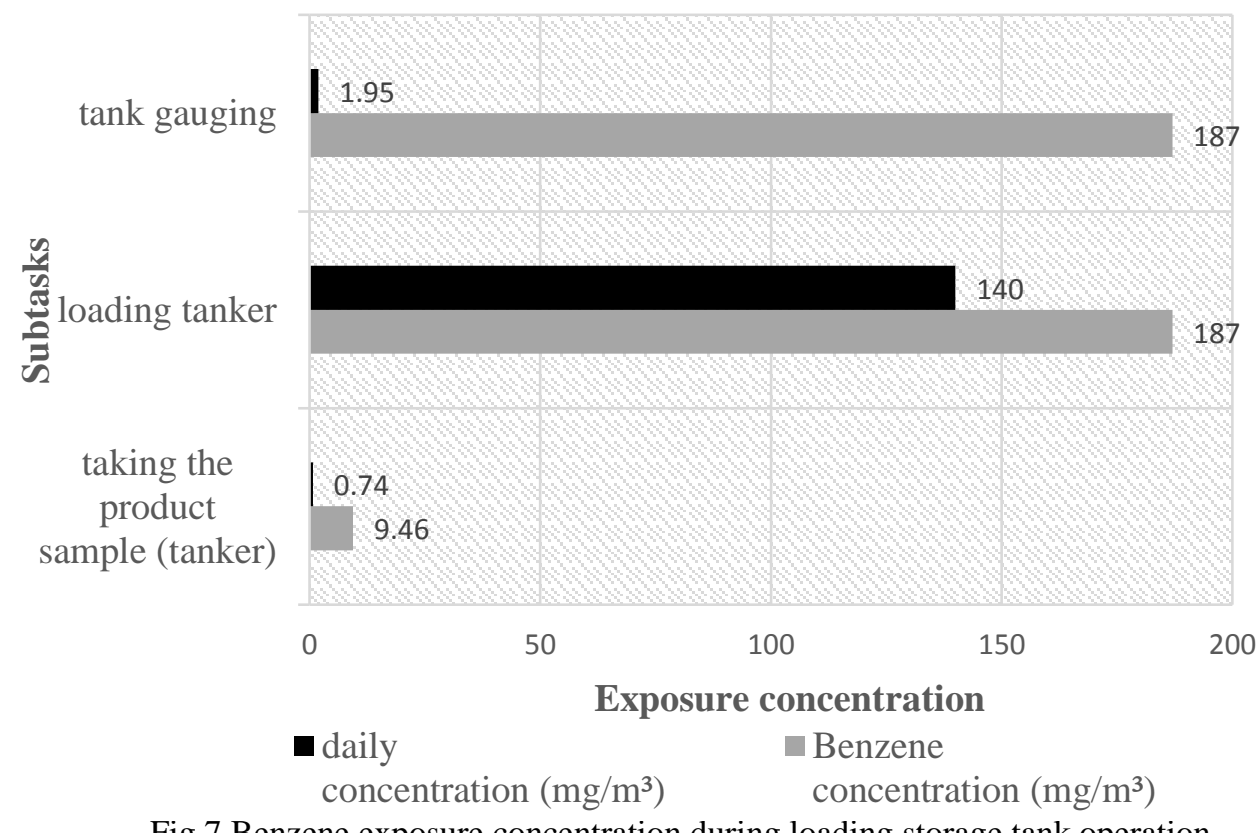

Fig.7 Benzene exposure concentration during loading storage tank operation. 


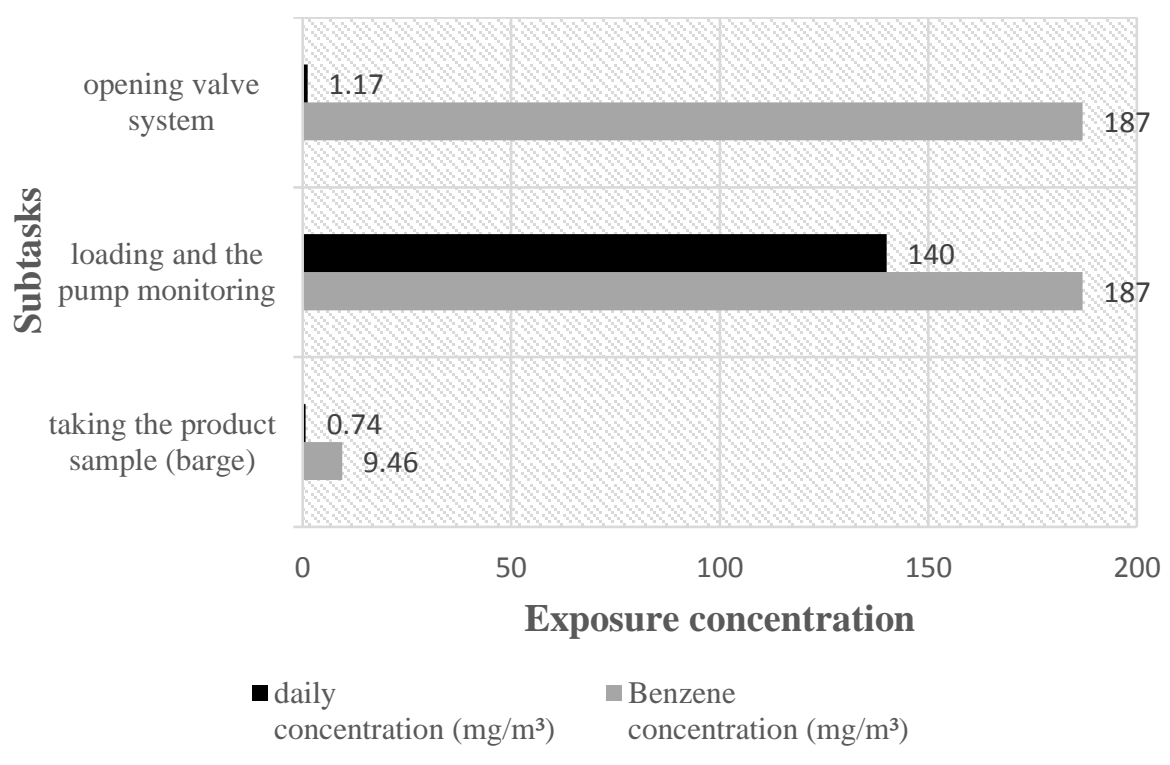

Figure 8. Benzene exposure concentrations during loading barge operation.

\subsubsection{Summary of estimated benzene exposure concentrations}

The benzene exposure concentration for the subtasks of each loading operations exceeded the $8.1 \mathrm{mg} / \mathrm{m}^{3} \mathrm{limit}$ for STELTVL from the ACGIH. Additionally, a high concentration up to $187 \mathrm{mg} / \mathrm{m}^{3}$ for STEL-TVL regarding the ACGIH regulation was indicated. The subtasks with the highest concentrations were "checking the manholes" and "loading truck tank" for " "loading truck tank operation"; " "tank gauging" for "loading storage operation"; " opening valve system" and "loading and the pump monitoring" for "loading barge operation'. Thus, the task-level assessment strategy discloses some critical benzene concentrations for STES during the loading operations [14]. The LTES, i.e., "loading and the pump monitoring", and "loading storage tank" had $140 \mathrm{mg} / \mathrm{m}^{3}$ and $140 \mathrm{mg} / \mathrm{m}^{3}$ benzene exposure for daily benzene concentration, respectively. These concentrations were significantly above the $3.18 \mathrm{mg} / \mathrm{m}^{3}$ OELs of the TVL-TWA from ACGIH. Daily benzene concentrations for LTES were higher in comparison to the STES. The results also indicate that the 8 hour-TWA of the subtask influences the benzene concentration in the breathing zone (Robert et al., 2010). In the present study, concentrations of benzene exposure to workers are critical for the three loading operations, due to the presence of very high benzene concentrations at the task-level within each of the subtasks. The reduction of the benzene concentration to the OELs for STEL-TVL with regards to ACGIH regulation remains urgent for the Gabon's GSDF.

\subsection{Benzene exposures reduction during loading operations}

The STES of the three loading operations ("loading truck tank operation", "'loading storage tank" operation and "loading barge" operation) selected in this facility indicated critical benzene concentrations. These results indicate an urgent need for reduction of the benzene concentrations at the task-levels to the OELs of STEL-TVL in reference to ACGIH guidelines. The Table 5. presents benzene exposure concentrations for all the subtasks before and after the implementation of the control measures. This table also shows a list of control measures used in order to make effective the reduction in benzene exposure concentrations to the OELs.

\subsubsection{Benzene exposure reduction for loading truck tank operation}

For the " truck tank loading", operation, control measures were applied to reduce benzene exposure concentrations on the subtasks: "checking the manholes", "cleaning spillage and leaks", and "taking the product sample", the equation (8) was used. On the subtask "loading truck tank", the equation (9) was used to reduce the benzene concentration for this subtask during the "truck tank loading operation". The results indicated an effective benzene concentration reduction from $187 \mathrm{mg} / \mathrm{m}^{3}$ to $4.55 \mathrm{mg} / \mathrm{m}^{3}$, for the subtask "checking the manholes" could be achieved by using a "vapor recovery system", and "chemical filter mask" for workers during the task. The "'loading truck tank" subtask indicated reduction in benzene concentration from $187 \mathrm{mg} / \mathrm{m}^{3}$ to $29.08 \mathrm{mg} / \mathrm{m}^{3}$, resulting from the use of "vapor recovery system", "quick shut-off valves" [34], and "chemical filter mask" as control measures. The "cleaning spillage and leaks"' subtask indicated benzene reduction from $27.65 \mathrm{mg} / \mathrm{m}^{3}$ to $4.52 \mathrm{mg} / \mathrm{m}^{3}$ with the use of "chemical filter mask", and "standing at the opposite direction from the wind when cleaning" during "'loading truck tank". The subtask "taking the product sample" indicated benzene reduction from $9.74 \mathrm{mg} / \mathrm{m}^{3}$ to $4.55 \mathrm{mg} / \mathrm{m}^{3}$, resulting from the use of "chemical filter masks", and "manila ropes". All the subtasks from the "truck tank loading"' operation, except the "loading truck tank" was within 
the $8.1 \mathrm{mg} / \mathrm{m}^{3}$ OELs of the STEL-TLV with regards to ACGIH guidelines. The results of subtask "loading truck tank" illustrates that, other strong external factors can render the control measures less effective in reducing benzene exposure, particularly benzene levels content in gasoline [35], in some developing countries.

\subsubsection{Benzene exposure reduction for loading storage tank operation}

In order to reduce benzene concentrations resulting from "loading storage tank" operation, control measures were applied to the subtasks: "tanker gauging"; "'loading storage tank", and "taking product sample". The equation (8) was implemented for the subtasks: "tank gauging"; and "taking product sample". The equation (9) was implemented for the subtask "loading storage tank" during "loading storage tank" operation. At the "tank gauging" subtask, the use of "chemical filter masks"; "floating roofs"; a "closed vent system"; "'emissions control device", as control measures while performing the task, reduced the benzene concentration from $187 \mathrm{mg} / \mathrm{m}^{3}$ to $4.55 \mathrm{mg} / \mathrm{m}^{3}$. The installation of "floating roofs"; a "closed vent system",; "emissions control device",; "making multiple moves out of the breathing zone", instead of being near the connected pipeline during the "loading storage tank" subtask, reduced the concentration from $187 \mathrm{mg} / \mathrm{m}^{3}$ to $4.55 \mathrm{mg} / \mathrm{m}^{3}$. The concentrations resulting from the subtask "taking the product sample", were reduced from 9.46 $\mathrm{mg} / \mathrm{m}^{3}$ to $4.55 \mathrm{mg} / \mathrm{m}^{3}$, by using 'chemical filter masks' and, 'manila ropes' as control measures. These results indicate that the use of appropriate technical measures, protective personal gear, and best practice control measures are effective for benzene reduction on "loading storage tank" operation at the Gabon's GSDF.

\subsubsection{Benzene exposure reduction for loading barge operation}

The equation (8) was applied for the subtasks: "taking product sample" and "opening valve system" to reduce benzene exposure during "loading barge" operation. The equation (9) was implemented for the subtask, "loading and the pump monitoring" during " loading barge" operation. The reduction of benzene exposure at the "barge loading" operation, was performed through control measures at the subtasks: "opening valve system", "taking the product sample", and "loading and the pump monitoring"'. The subtask "opening valve system", by using a "chemical filter mask", "steel valves", and "standing at the opposite direction from the wind" as control measures, reduced the benzene concentration from $187 \mathrm{mg} / \mathrm{m}^{3}$ to $4.55 \mathrm{mg} / \mathrm{m}^{3}$. The subtask "taking the product sample", with the use of a "chemical filter masks", "manila ropes", and "standing at the opposite direction from the wind", reduced the benzene concentration from 178 $\mathrm{mg} / \mathrm{m}^{3}$ to $4.55 \mathrm{mg} / \mathrm{m}^{3}$. The "benzene concentration", of the subtask "loading and the pump monitoring", was reduced from $187 \mathrm{mg} / \mathrm{m}^{3}$ to $4.55 \mathrm{mg} / \mathrm{m}^{3}$, by using a "vapor recovery system', "'chemical filter masks", and "'standing at the opposite direction from the wind" as control measures. The Fig. 9 presents benzene exposure concentration of each of the subtasks before and after applying the control measures. The results imply that technical control measures and work practice control measures are the most effective determinants of benzene exposure reduction at the Gabon's GSDF for "barge loading" operation. The results of benzene reduction on the subtasks " opening valve system", "taking product sample", and "loading and the pump monitoring" show that, the implementation of engineering control measures, appropriate best practices, as well as technical and protective personal control measures could effectively reduce the benzene masks", and "standing at the opposite direction from the wind"' as control measures. The Fig. 9 presents benzene exposure concentration of each of the subtasks before and after applying the control measures. The results imply that technical control measures and work practice control measures are the most effective determinants of benzene exposure reduction at the Gabon's GSDF for "barge loading", operation. The results of benzene reduction on the subtasks " opening valve system", "taking product sample", and "loading and the pump monitoring" show that, the implementation of engineering control measures, appropriate best practices, as well as technical and protective personal control measures could effectively reduce the benzene concentration for "loading barge" operation in this facility. 
Table 5. Benzene concentrations before and after applying the control measures

\begin{tabular}{|c|c|c|c|c|c|}
\hline \multicolumn{4}{|c|}{ Before applying control measures } & \multicolumn{2}{|l|}{ After applying control measures } \\
\hline No & Operation & Tasks & \begin{tabular}{|l|} 
Task \\
concentration \\
$\left(\mathbf{m g} / \mathbf{m}^{3}\right)$
\end{tabular} & Control measures & $\begin{array}{l}\text { Task } \\
\text { concentration } \\
\left(\mathbf{m g} / \mathbf{m}^{3}\right)\end{array}$ \\
\hline 1 & \multirow{4}{*}{$\begin{array}{l}\text { Truck } \\
\text { tank } \\
\text { loading }\end{array}$} & $\begin{array}{l}\text { checking } \\
\text { manholes }\end{array}$ & 187 & $\begin{array}{l}\text { vapor recovery system + chemical } \\
\text { filter mask }\end{array}$ & 4.55 \\
\hline 2 & & loading truck tank & 187 & $\begin{array}{l}\text { vapor recovery system }+ \text { quick shut- } \\
\text { off valves }+ \text { chemical filter mask }\end{array}$ & 29.08 \\
\hline 3 & & $\begin{array}{l}\text { cleaning spillage } \\
\text { and leaks }\end{array}$ & 27.65 & $\begin{array}{l}\text { chemical filter mask }+ \text { personal } \\
\text { protective equipment }+ \text { standing in } \\
\text { the opposite direction of wind }\end{array}$ & 4.52 \\
\hline 4 & & \begin{tabular}{|l} 
taking the product \\
sample \\
tank)
\end{tabular} & 9.74 & $\begin{array}{l}\text { chemical filter mask }+ \text { standing in the } \\
\text { opposite direction of wind + manila } \\
\text { ropes }\end{array}$ & 4.55 \\
\hline 5 & \multirow{3}{*}{$\begin{array}{l}\text { Storage } \\
\text { tank } \\
\text { loading }\end{array}$} & tank gauging & 187 & $\begin{array}{l}\text { chemical filter mask + floating roofs } \\
+ \text { closed vent system }+ \text { emissions } \\
\text { reduce device }\end{array}$ & 4.55 \\
\hline 6 & & $\begin{array}{l}\text { Loading storage } \\
\text { tank }\end{array}$ & 187 & $\begin{array}{l}\text { floating roofs }+ \text { closed vent system }+ \\
\text { emission reduce device }+ \text { chemical } \\
\text { filter mask }\end{array}$ & 4.55 \\
\hline 7 & & $\begin{array}{l}\text { taking } \\
\text { sample }\end{array}$ & 9.46 & $\begin{array}{l}\text { chemical filter mask }+ \text { standing in the } \\
\text { opposite direction of wind + manila } \\
\text { ropes }\end{array}$ & 4.55 \\
\hline 8 & \multirow{3}{*}{$\begin{array}{l}\text { Barge } \\
\text { loading }\end{array}$} & $\begin{array}{ll}\text { opening } & \text { valve } \\
\text { system } & \end{array}$ & 187 & $\begin{array}{l}\text { chemical filter mask }+ \text { steel valves }+ \\
\text { multiples moves out of breathing } \\
\text { zone }\end{array}$ & 4.55 \\
\hline 9 & & $\begin{array}{l}\text { loading and the } \\
\text { pump monitoring }\end{array}$ & 187 & $\begin{array}{l}\text { vapor recovery system + Chemical } \\
\text { filter mask }\end{array}$ & 4.55 \\
\hline 10 & & $\begin{array}{l}\text { taking the product } \\
\text { sample (barge) }\end{array}$ & 178 & $\begin{array}{l}\text { chemical filter mask }+ \text { standing in the } \\
\text { opposite direction of wind }+ \text { manila } \\
\text { ropes }\end{array}$ & 4.55 \\
\hline
\end{tabular}

The results of this study, for most subtasks, were similar to those obtained in the first previous studies on exposure to benzene during loading operation from industrialized countries, such as those of: Irving et al., (130 ppm); Nordlinder et al., report (33.44 ppm during manual sounding); Saarinen., et al., (3030 mg/m³ during tanker loading), and Smith et al., (130 ppm during truck tank loading). 


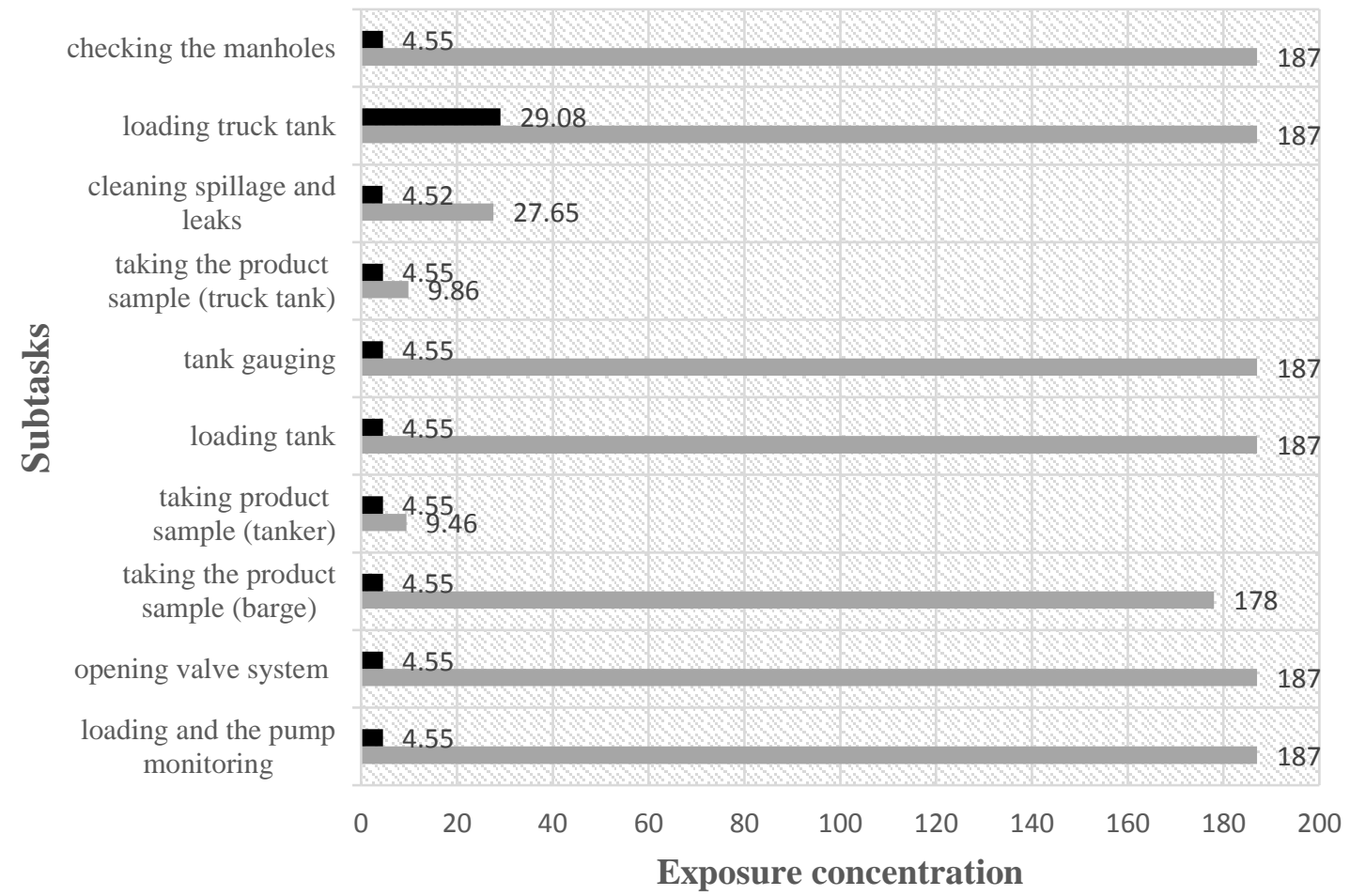

- after applying control
measure $\left(\mathrm{mg} / \mathrm{m}^{3}\right)$

before applying
control measures $\left(\mathrm{mg} / \mathrm{m}^{3}\right)$

Figure 9. Benzene concentrations before and after applying the control measures

However, the results from this study were not without limitations. The results of this study cannot be generalized to represent loading operations as the only source emission of benzene exposure in Gabon's GSDF. This study did not take into account the risk of benzene exposure during regular maintenance and repair subtasks, which could also increase the level of benzene concentration exposure to workers in the facility. Additionally, the automation of loading operations as a control measure, which could avoid workers to those high benzene exposure concentration subtasks in that facility, was not be evaluated. Despite these study limitations, the study was worthwhile in its short-term exposure assessment of benzene and its reductions with regards to OELs at the Gabon's GSDF.

\section{CONCLUSION}

This study evaluated the benzene exposure concentration and the effectiveness of systematic introduction of control measures at the Gabon's GSDF during loading operations. The estimation methodology provided benzene exposure concentration of each of the subtasks and helped elucidate the level of prevention needed to alleviate worker health risks. Additionally, this study determined effective control measures that keep the exposure concentrations of the subtask below the OELs to offer a safe working place to the workers. This is particularly relevant to facilities lacking of relevant exposure concentration data and accurate risk assessment expertise. The estimated benzene concentrations varied from $9.46 \mathrm{mg} / \mathrm{m}^{3}$ to $187 \mathrm{mg} / \mathrm{m}^{3}$ for all subtasks, in the three loading operations. The highest benzene concentrations $\left(187 \mathrm{mg} / \mathrm{m}^{3}\right)$ were found in subtasks such as "checking the manholes"; "loading truck tank"; "tank gauging"; " loading tank"; "loading and the pump monitoring", and “opening valve system”. The benzene concentration for STET varied from $9.46 \mathrm{mg} / \mathrm{m}^{3}$ to 187 $\mathrm{mg} / \mathrm{m}^{3}$ and significantly exceeded the $8.1 \mathrm{mg} / \mathrm{m}^{3}$ OELs of the STEL-TVL prescribed by the ACGIH. The LTES were 187 $\mathrm{mg} / \mathrm{m}^{3}$ significantly exceeded the $3.18 \mathrm{mg} / \mathrm{m}^{3}$ OELs of the TVL-TWA from the ACGIH guidelines. The reduction of benzene exposure concentration varied from $4.52 \mathrm{mg} / \mathrm{m}^{3}$ to $29.08 \mathrm{mg} / \mathrm{m}^{3}$ for all the subtasks. The reduction was within the $8.1 \mathrm{mg} / \mathrm{m}^{3}$ OELs of STEL-TVL from the ACGIH guidelines. The implementation of control measures based on the S.T.O.P.-principal (substitution, technical measures, operations measures, personal protection equipment) enabled the evaluation of appropriates control measures in each of the groups, such as "vapor recovery system" control measure from 
the group of "technical measures"; and "chemical filter mask" from the group "personal protective equipment" for effective reduction of benzene concentrations. This study examined and estimated the level of exposure to the carcinogen benzene during loading operations in Gabon's GSDF, focused on assessing short-term high exposure subtasks and systematically evaluate the control measures. The study results are expected to help improve the regulation level and assess workers' health in that facility.

\section{ACKNOWLEDGEMENTS}

This research would have not been possible without the support of several people. The authors would like to thanks to all those who cooperated and participated in this research, including Dr. Leticia Dos Muchangos of Osaka University, the Health, Safety, Environment manager of Oilibya-Gabon Marcelin Nguema Mba. This research was completed with support from the Ministry of Education, Culture, Sports, Science, and Technology of Japan, (Grant No. 150768) through its postgraduate scholarship program for foreign students.

\section{REFERENCES}

[1] Carolyn F. Phillips CF, Robert K. JONES RK. Gasoline vapor exposure during bulk handling operations. American Industrial Hygiene Association Journal. 1978; Volume 39: 1978 - Issue 2/ Pages 118-128.; 04 Jun 2010.

[2] J. Paul Guyer 2014. An Introduction to Petroleum Fuel Facilities: Bulk Fuel Storage Continuing Education and Development, Inc. 9 Grey ridge Farm Court. Stony Point, NY 10980. [3] G.H.Pandya, A.G. Gavane and V.K. Kondawar. Assessment of Occupational Exposure to VOCs at the Gantry Gasoline Terminal. JOURNAL OF ENVIRON. SCIENCE \& ENGG. VOL. 48, No. 3, P. 175 -182, July 2006.

[4] U.S.EPA-450. CONTROL OF HYDROCARBONS FROM TANK TRUCK GASOLINE LOADING TERMINALS. EPA-450/2-77-026 (OAQPS NO. 1.2-082).

[5] IARC (1987). Overall evaluations of carcinogenicity: an updating of IARC Monographs volumes 1 to 42. IARC Monogr Eval Carcinog Risks Hum Suppl, 7: 1-440. PMID:3482203

[6] Ormrat Kampeerawipakorn, Panida Navasumrit, Daam Settachan, Jeerawan Promvijit Potchanee Hunsonti, Varabhorn Parnlob, Netnapa Nakngam, Suppachai Choonvisase, Passaornrawan Chotikapukan, Samroeng Chanchaeamsai, Mathuros Ruchirawat. Health risk evaluation in a population exposed to chemical releases from a petrochemical complex in Thailand. Environmental Research, Volume 152, January 2017, Pages 207-213 https://doi.org/10.1016/j.envres.2016.10.004

[7] Benjamin Edokpolo B, Qiming Jimmy Yu QJ, and Des Connell D. Health risk assessment of ambient air concentrations of benzene, toluene and xylene (BTX) in service station environments. Int. J. Environ. Res. Public Health 2014; 11(6), :6354-6374.; http://dx.doi.org/doi:10.3390/ijerph110606354.

[8]. Keretetse G.S., Laubscher P.J., du Plessis J.L., Pretorius P.J., van der Weshuizen F.H., van Dyk E., Eloff F.C., Arde M.N., du Plessis L.H. DNA damage and repair detected by the comet assay in lymphocytes of African petrol attendants: A pilot study. Ann. Occup. Hyg. 2008`; 52:653-662. http://dx.doi:10.1093/annhyg/men047. [PubMed] [CrossRef]

[9] Cheremisinoff and Morresi, 1979; P.N. Cheremisinoff, A.C. Morresi. Benzene, Basic and Hazardous Properties. Marcel Dekker, New York (1979), p. 250. Google Scholar.

[10] Diane Bignoumba; Christophe Gibout. Les enjeux de la gestion du risk environnemental dans la zone de N'toum au Gabon: Cas de l'entreprise CIMGABON. HAL/archives-ouvertes.fr https://tel.archives-ouvertes.fr/tel-01020557, mardi 8 juillet 2014 .

[11] Gabonese Republic. Arrête No. 001072/MMEPRH, Instituant la realization des etudes de dangers pour les installations petrolieres classees, implantees en Republique Gabonaise. 29 Octobre 2007.

[12] R. Cecil, R. J. Ellison. Exposure profile: gasoline. CONCAWE report no. 97/52, Brussels January 97.

[13] Storage and Handling of Petroleum Products at Depots and Terminals Report. 2015, www.oisd.gov.in

[14] Julie M. Panko, Shannon H. Gaffney, Amanda M. Burns. Occupational Exposure to Benzene at the Exxon Mobil Joliet, Illinois, USA (1977-2006). Toxicology and Industrial Health journal, 26(10) 671-690, 2010.

[15] Martie van Tongeren, Judith Lamb, John W Cherrie, Laura Mac Colman, Ioan nis Basinas, Susanne Hesse. Validation of Lower Tier Exposure Tools Used for REACH: Comparison of Tools Estimates With Available Exposure Measurements. Annals of Work Exposures and Health, Volume 61, Issue 8, 1 October 2017, Pages 921-938, https://doi.org/10.1093/annweh/wxx056 
[16] Susanne Bredendiek-Kämper. Do EASE Scenarios Fit Workplace Reality? A Validation Study of the EASE Model. Pages 182-187 | Published online: 30 Nov 2010. Download citation https://doi.org/10.1080/104732201460316

[17] M. TISCHER S. BREDENDIEK-KÄMPERU. POPPEK. Evaluation of the HSE COSHH Essentials Exposure Predictive Model on the Basis of BAuA Field Studies and Existing Substances Exposure Data. The Annals of Occupational Hygiene, Volume 47, Issue 7, 1 October 2003, Pages 557-569, https://doi.org/10.1093/annhyg/meg086

[18] Erik Tielemans, Dook Noy, Jody Schinkel, Henri Heussen, Doeke Van Der Schaaf, John West and Wouter Fransman. Stoffenmanager Exposure Model: Development of a Quantitative Algorithm. The Annals of Occupational Hygiene Volume 52, Issue 6Pp. 443-454, 2008. https://doi.org/10.1093/annhyg/men033

[19] Verma DK, Jim A. Julian JA, Gail Bebee G, Wai K. Cheng WK, Holborn K, Shaw L. Hydrocarbon exposures at petroleum bulk terminals and agencies. American Industrial Hygiene Association Journal 1992; 53(10): Pages 645-656, (1992). http://dx.doi.org/10.1080/15298669291360292

[20] Verma DK, Diane M. Johnson DM, M. Lorraine Shaw ML, Karen Des Tombe K. Benzene and Total hydrocarbons exposures in downstream petroleum industries. American Industrial Hygiene Association Journal, 2001;62:176194 (2001) Pages 176-194. http://dx.doi.org/10.1080/15298660108984621

[21] Karen Des Tombe, Dave K. Verma DK, des Tombe K. Measurement of benzene in the workplace and its evolution process, part I: Overview, history, and past methods. Journal American Industrial Hygiene Association Journal 1999; Volume 60: 1999 - Issue-1, Pages38-47. http://dx.doi.org/10.1080/00028899908984421

[22] Derek Swick D, Andrew Jacques A, J.C. Walker JC, Herb Estreiche H. Gasoline risk management: a compendium of regulations, standards, and industry practices. Regulatory Toxicology and Pharmacology 2014; 70: (2014) S80S92. https://doi.org/10.1016/j.yrtph.2014.06.022

[23] Benzene reduction regulation (U.S. EPA, 1990)

[24] Direct infos (l'actualite financieres et economiques du Gabon) https://directinfosgabon.com/le-petrole-2/

[25] Stephen J. Lewis SJ, Gary M. Bell GM, Neil Cordingley N, Eileen D. Pearlman ED, Lesley Rushton L. Retrospective estimation of exposure to benzene in leukaemia case-control study of petroleum marketing and distribution workers in United Kingdom. Occupational and Environmental Medicine 1997; 54:167-175. http://dx.doi.org/10.1136/oem.54.3.167.5-163

[26] John W. Cherrie and Thomas Schneider. Validation of a New Method for Structured Subjective Assessment of Past Concentrations. Annals of occupational Hygiene, 1998. Pages 235-245, https://doi.org/10.1093/annhyg/43.4.235

[27] Dorothea Koppisch, Jody Schinkel, Stefan Gabriel, Wouter Fransman, Erik Tielemans. Use of the MEGA Exposure Database for the Validation of the Stoffenmanager Model. The Annals of Occupational Hygiene, Volume 56, Issue 4, 1 May 2012, Pages 426-439, https://doi.org/10.1093/annhyg/mer097 Published: 07 November 2011 Article history

[28] Hanna E. Landberg, Anna Axmon, Håkan Westberg, Håkan Tinnerberg. A Study of the Validity of Two Exposure Assessment Tools: Stoffenmanager and the Advanced REACH Tool. Ann Work Expo Health (2017) 61 (5): 575 588. https://doi.org/10.1093/annweh/wxx008

[29] Stoffenmanager', a Web-Based Control Banding Tool Using an Exposure Process Model. Hans Marquart, Henri Heussen, Maaike Le Feber, Dook Noy, Erik Tielemans, Jody Schinkel, John West, Doeke Van, Der Schaaf. The Annals of Occupational Hygiene, Volume 52, Issue 6, 1 August 2008, Pages 429-441, https://doi.org/10.1093/annhyg/men032 Published: 27 June 2008

[30] Stoffenmanager Exposure Model: Development of a Quantitative Algorithm. Erik Tielemans Dook Noy Jody Schinkel, Henri Heussen, Doeke Van, Der Schaaf. John West, Wouter Fransman. The Annals of Occupational Hygiene, Volume 52, Issue 6, 1 August 2008, Pages 443-454, https://doi.org/10.1093/annhyg/men033. Published: 10 July 2008

[31] ERIK TIELEMANS1, THOMAS SCHNEIDER. Conceptual Model for Assessment of Inhalation Exposure: Defining Modifying Factors. Annals of occupational. The Annals of Occupational Hygiene, Volume 52, Issue 7, 1 October 2008, Pages 577-586, https://doi.org/10.1093/annhyg/me

[32] W.S. Irving WS, Thomas G. Grumbles TG. Benzene exposures during gasoline loading at bulk marketing terminals. American Industrial Hygiene Association, J 1979;40:468-736. http://dx.doi.org/10.1080/15298667991429840. Toxicology Letters, 52 (1900) 135-139, 1990. 
[33] Robert C. Spear RC, Steve Selvin S, Jane Schulman J, and Marcie Francis M. Benzene exposure in the petroleum refining industry. Applied Industrial Hygiene. 1987; VOL. 2: NO. 4. July 1987. Pages 15.

[34] Lauri Saarinen L. Recent development of exposure to gasoline in the distribution chain Lauri Saarinen. Kuopio (Finland): University of Kuopio; 2002. People and Work Research Reports No.:15.

[35] Haji Bahabar, Sara Mostafalou, Mohammad Abdollahi. Current understanding and perspectives on non-cancer health effects of benzene: A global concern. Toxicology and Applied Pharmacology 276(2014) 83-94. https://doi.org/10.1016/j.taap.2014.02.012

[36] Nordlinder R, Ramnas O. EXPOSURE TO BENZENE AT DIFFERENT WORK PLACES IN SWEDEN. The Annals of Occupational Hygiene, Volume 31, Issue 3, 1 January 1987, Pages 345-355, https://doi.org/10.1093/annhyg/31.3.345

[37] Thomas J. Smith TJ, S. Katharine Hammond SK, Otto Wong O. Health effects of gasoline exposure. I. exposure assessment for U.S. Distribution Workers. Environmental Health Perspectives Supplements 1993; 101: (Suppl.6): 13-21. http://dx.doi.org/10.1080/08828032.1987.10390543.

[38] T. Kawai, K. Yamaoko, Yoko Uchida and Masayuki Ikeda. Benzene exposure in a Japanese petroleum refinery https://doi.org/10.1016/0378-4274(90)90147-E 